\title{
The Impact of Seasonal Differences on Fish Species Diversity, Price Fluctuations, and Fishermen Welfare on Baron Beach Gunung Kidul
}

\author{
David Safri Anggara ${ }^{1, *}$, Nur Ahmad Rudin ${ }^{2}$ \\ ${ }^{1}$ Prodi Pengembangan Masyarakat Islam, Fakultas Dakwah dan Komunikasi, UIN Sunan Kalijaga \\ Jl. Marsda Adisucipto, Papringan, Caturtunggal, Kec. Depok, Kabupaten Sleman, Daerah Istimewa Yogyakarta \\ ${ }^{2}$ Departement of Tropical Biology, Faculty of Biology, Universitas Gadjah Mada \\ Jl. Teknika Selatan, Senolowo, Sinduadi, Mlati, Kabupaten Sleman, Daerah Istimewa Yogyakarta 55281, Indonesia \\ Email*: davidsafrianggara@gmail.com
}

\begin{abstract}
Gunungkidul Regency has $73 \mathrm{~km}$ of coastline and potential to be developed as center of economic growth based on the utilization of marine fisheries resources. Baron Beach is one of the tourism destination, also has function for fish auction (TPI) and market that caught by fishermen. Seasonal differences affect the conditions of tides and have impact on fishing activities. This makes important for conducted this research. Therefore, this study was conducted to determine the effect of seasonal differences on diversity of fish species and welfare of fishermen on Baron Beach. This research is a qualitative descriptive and was carried out with observation and in-depth interviews with traders, fishermen, and consumers. Data analysis was performed using the Miles and Hubberman methods. The results showed the harvest season occurred in the transition season and mid-rain on October until January. The diversity of fish species at most in this season are Euthynnus affinis, Elagatis bipinnulata, Katsuwonus pelamis, Scomberomorus sp. and Selar crumenophthalmus. Diversity at most on the rainy season is Pampus argenteus, while in the dry season are Stolephorus sp., Elagatis bipinnulata, and Auxis rochei. The method of selling fish was done through fishermen, brought to the fish auction to bought by collectors, traders, and consumers. The selling price of fish on traders and collectors has doubled from the fishermen. The abundance of crops has an impact on welfare of fishermen, consumers and traders. The harvest season also has positive impact on social, tourism and culture. The conclusion from this study is the seasonality affects to diversity of fish species, selling price is relatively stable, and has positive impact on society in terms of economic, social, cultural and tourism.
\end{abstract}

Keywords: Baron Beach, diversity, fisherman, price, seasonal, welfare.

\section{INTRODUCTION}

Gunungkidul Regency has $73 \mathrm{~km}$ of coastline and make Gunungkidul has wider fishing catchment area compared to fishermen on other region in Yogyakarta. This condition is potential to be developed as a center of economic growth based on the utilization of marine fisheries resources and can be used for economic activities in the community and region. Sahubawa et al. (2015) projected a potential value of fisheries on Gunungkidul coast is 64 billion rupiahs. The fisheries sector activities in Gunungkidul have an important role in the production of marine fisheries with $83.3 \%$ of sea fish production in Yogyakarta originating from Gunungkidul Regency. The marine fish production reached 4,457 tons in 2014 (BPS, 2016). This number is the highest compared to other districts in Yogyakarta that have a coastline, Bantul and Kulonprogo. Production value of sea fish on Gunungkidul is also the highest in Yogyakarta for 2014 which amounted to 29 billion or $60 \%$ of the total production value. This large production value should have an impact on regional economic activity. The fisheries sub-sector has the potential to be a trigger for development in the southern part of Gunungkidul Regency.
Baron Beach is one of the beaches that developed to support fisheries production in Gunungkidul Regency. Baron Beach is located in Desa Kemadang Village, District of Tanjungsari, Gunungkidul Regency. In the last five years $(2012-2016)$, the number of tourists on Baron Beach increased from 782,656 to $1,946,555$ visitors. This indicates an increase of $248.71 \%$ (Tourism Visitor Data from 2012 - 2016), making this beach ranked first in the highest number of tourists in Gunungkidul Regency. Various tourism potentials are found on this beach. Baron Beach is one of the tourism destinations, also has functions for fish auctions (TPI) and markets that are caught by fishermen (Kusumastuti and Pamungkas, 2018).

Seasonal differences affect the conditions of tides and have an impact on fishing activities. Oceanographic dynamics play a role in regulating the behavior of fish. Some parameters of the condition from marine environment include sea water temperature, ocean currents, salinity, and food availability. Temperature is an oceanographic parameter that has a very dominant influence on fish life. Each type of fish has an optimum temperature for its life (Hela and Laevastu, 1970). Knowledge of the optimum temperature of a fish species can be used as a basis for predicting the existence of fish. 
At suitable temperature conditions, fish tend to have a better appetite. Group of fish are usually found at the junction between two water masses that have difference temperature (front temperature). The front temperature is characterized by a meeting of the mass of cold water with the surrounding water mass which has a temperature difference of $1-2^{\circ} \mathrm{C}$ (Mann and Lazier 1996). Besides temperature, the migration of fish naturally follows the pattern of current movement as a fish orientation tool (Lavastu and Hayes 1981).

Ocean currents can be tidal currents or globally water mass movements. Group of fish are usually found in the junction area between two currents (front currents). While salinity affects biological processes that directly affect the growth rate, amount of food, conversion value of food, and survival. Besides being influenced by oceanographic conditions, fish abundance is also very dependent on food availability. Fish resources occupy the top and middle trophic levels in sea food chain. Its abundance and presence depend on the amount of biomass at lower trophic levels, namely phytoplankton and zooplankton (Qu et al., 2005). The oceanographic conditions affect the abundance of fish which causes differences in fish harvest season. This makes important to conducted this research. Therefore, this study was conducted to determine the effects of seasonal differences on fish species diversity and welfare of fishermen on Baron Beach.

\section{MATERIALS AND METHODS}

\section{Study area}

This research is located in Baron Beach, Desa Kemadang, Tanjungsari, Gunungkidul. This beach in southern area of Gunungkidul or about $40 \mathrm{~km}$ from the main city. The reasons of researcher choose Baron Beach as the location; firstin the view last month's, fisherman's in the baron beach gain abundant of fish because of seasonal change, second even baron beach became one of the most favorite tourism destination, fisherman's in baron is still many. Third Baron Fisherman's have unique way to forecasting harvest season, basically most of them used Java calendar or kaleidoscope. The last, this research is actual because there isn't similar research which is focusing on social wealth during seasonal difference in Baron Beach.

\section{Procedures}

This research is descriptive - qualitative, it is providing a systematic, factual, and comprehensive written description of the relationship between phenomena to phenomena that must be examined (Rizky, 2018). This method used observation and in-depth interview to some informant, which are Baron beach fish sellers, head chief of baron beach fisherman (Mina Boga), buyers who lived near baron beach, and randomly Baron visitors.

\section{Data analysis}

In analyzing the data, Researcher used Miles and Hubberman methods, namely data collection, data reduction, data presentation and conclusion drawling (Miles and Hubberman, 2019)

\section{RESULTS AND DISCUSSION}

\section{Baron Fishermen}

All the fishermen in Baron Beach are members of Mina Samodra fishing group. It was established in 1983 by people of Kemadang, Tanjungsari, Gunungkidul. Previously, In several decade Baron Beach was only used for fishier sector, but right now Baron Beach has become most popular tourism destination in Gunungkidul. Even Though there were still trees and large ships that not well organized (Thoyib, 2019). Therefore, with the formation of Mina Samudra Group, it would be help to organized fishermen, ships, and also makes it easier in guiding and managing fisihing aids from the government.

\section{Technology of Catching Fish on the Baron Coastal}

The Technology used by Baron Coast Fisherman became important factor which is determine amount of fish catches. There are some technology or tools used by fishermen to catching fishermen.

a. Outboard or Jungkung's Ship

At least there are $25-30$ ships which is used by Baron Fishermen for fisihing in the sea and tourist activity. The price of this ships rages from 50 million until 60 million depending on motor engines and fiberglass. In this season (October - November 2019) one ship could carried 2000 until 30000 kilograms once at sea.

b. Long lining Fishing Rod (Pancig Rawai)

This fisihing rod is actually commonly used to catch fish in some places especially java. The Shape is a single long line which is hanging baited hooks around $50-100 \mathrm{~km}$. Usually this fishing line is used to catch big fish like tuna, cakalang, bandeng, octopus, and etc.

c. Sea Fishing Nets

The length nets who used by Baron Fishermen is usually about 400 meters and 7 meters wide, while the size of smalls nets is 3 meters long with a width about 5 meters. The nets is used while in the middle of the sea by spreading it.

d. Krendet

This tools is usually used by fishermen to catch lobster and certain fish. Krendet is passively used because it assembled with bait in the bottom of waters around the coral reefs. After being left for a day or few days the Krendet could be lifted up, then the trapped lobster or fish can be taken. 


\section{Fish Diversity}

The harvest season occurred in the transition season and mid-rain on October until January. The diversity of fish species at most in this season are Euthynnus affinis, Elagatis bipinnulata, Katsuwonus pelamis, Scomberomorus sp. and Selar crumenophthalmus. Diversity at most on the rainy season is Pampus argenteus, while in the dry season are Stolephorus sp., Elagatis bipinnulata, and Auxis rochei.

Euthynnus affinis (Cantor, 1849) is an epipelagic, neritic species in habiting waters temperatures ranging from 18 to $29^{\circ} \mathrm{C}$. Although sexually mature fish may be encountered throughout the year, there are seasonal spawning peaks varying according to regions and from August to October in Indonesia (Collette and Nauen, 2019). This species is widespread and abundant in the Indian and Western Pacific Ocean. It is caught in commercial fisheries, primarily as by catch. It is marketed in a variety of products, and reported worldwide landings are increasing. This pelagic and oceanodromous species occurs in open waters, but it always remains close to the shoreline. It is found to $50 \mathrm{~m}$ depth. The young may enter bays and harbours. It forms multi-species schools by size with other scombrid species, comprising from 100 to over 5,000 individuals. This species is generally marketed canned and frozen. It is also utilized dried, salted, smoked and fresh. It is important in highly commercial fisheries. This species is used in pet food for dogs and cats (Collette 2001).

Elagatis bipinnulata (Quoy and Gaimard, 1824) is a pelagic fish,usually found at or near the surface $(0-15$ $\mathrm{m})$, over coral and rocky reefs or sometimes far offshore; may form sizeable schools. Feeds on crustaceans, small fishes and squid.This pelagic species is widely distributed, common and locally abundant. It is harvested for food and sport in most of its range. Elagatis bipinnulata is circumtropically distributed. In the Indo-Pacific it is known along East Africa, the Red Sea, India, Thailand, Indonesia, the Philippines, Japan, Australia, New Zealand, and the Hawaiian Islands. Elagatis bipinnulata is harvested for food and is a popular game fish; caught mainly with hook and line, gillnets and seines; marketed fresh and dried salted (Smith-Vaniz 2002). There are no existing large-scale fisheries; it is generally caught incidentally by artisanal or recreational fishermen (Pinheiro et al., 2011). It is targeted for food in the Philippines and Colombia (Maypa et al., 2002). It is also caught as bycatch in the tuna purse seine fishery. It is an important component of the small-scale pelagic fishery in San Andres Island, Occidental Caribbean (Gonzalez and Olarte 2004) and a minor component of commercial fisheries in Cuba and Jamaica (Simon et al., 2013). It is harvested commercially by the Abu Dhabi Emirate fisheries (Environment Agency-Abu Dhabi 2006-2013). In the Gulf of Mexico, it occurs incidentally in commercial fisheries in very low numbers. It is also an incidental catch of recreational fishers in U.S. waters and landings statistics are not considered to be consistently reliable. This is different from Baron Beach fisherman which catches this fish as an abundant commodity in the harvest season.

Katsuwonus pelamis (Linnaeus, 1758) is an epipelagic, oceanic species, and oceanodromous species that found in offshore waters to depths of $260 \mathrm{~m}$. The larvae are restricted to waters with surface temperatures of $15-30^{\circ} \mathrm{C}$ in Australia. This species exhibits a strong tendency to school in surface waters with birds, drifting objects, sharks, and whales. This species feeds on fish, crustaceans, cephalopods, and molluscs. It is preyed upon by large pelagic fishes (Maunder, 2010). Aggregations of this species tend to be associated with convergences, boundaries between cold and warm water masses (i.e. the polar front), upwelling and other hydrographical discontinuities. Depth distribution ranges from the surface to about $260 \mathrm{~m}$ during the day, but is limited to near surface waters at night. Skipjack tuna spawn in batches throughout the year in equatorial waters, and from spring to early fall in subtropical waters, with the spawning season becoming shorter as distance from the equator increases. In the Indian Ocean this species is mainly caught by purse seine, gillnet and bait boat (IOTC 2008). The high productivity life history characteristics of Skipjack Tuna suggest this species is resilient and not prone to overfishing, and the stock status indicators suggest there is no need for immediate concern about the status of Skipjack Tuna. This species is important in highly commercial fisheries. This species is widespread and is important in commercial fisheries throughout its range. Although it is heavily fished, it is considered relatively abundant and is fast-growing, short-lived, and very fecund (Arai et al., 2005).

Scomberomorus sp. or mackerel fish has 3 three types in Indonesia, namely Scomberomorus commerson, Scomberomorus guttatus and Scomberomorus lineatus. Mackerel lives in many pelagic areas. All open areas are pelagic areas. Spread of mackerel in Indonesia includes of Sumatra, Java, Nusa Tenggara, Borneo, Celebes, Mollucas and Papua. It's relating with the potential distribution and capture areas in each of these waters. Scomberomorus sp. known in international trade as narrow-barred spanish mackerel has high economically value due to domestic demand and the world continues to rise and prices are increasingly high (Kasim and Triharyuni, 2014). Indonesia is largest producer of mackerel fish the world's. The latest data from FAO shows that Indonesia is still ranks first in the world as a producer mackerel fish with production value reached 147,059 tons in 2010 which came from two main fishing area in Indian Ocean as many as 29,359 tons and Pacific Ocean as much 117,700 tons (FAO, 2014).

Selar crumenophthalmus (Bloch, 1793) is widely distributed, common and locally abundant where it occurs in large inshore schools. Selar crumenophthalmus is distributed worldwide in tropical and subtropical 
marine waters. It's depth range is $1-170 \mathrm{~m}$. Selar crumenophthalmus occurs in large inshore schools, usually in shallow waters (Roos et al., 2007). It also occurs over shallow reefs or in turbid water. It can be associated with Whale Sharks (Smith-Vaniz et al., 2015). Selar crumenophthalmus is collected using hook and line, beach seines, trawls, purse seines and traps and is marketed fresh or dried salted and for fishmeal and oil. Its edibility is fair to good. It occurs as bycatch in commercial bottom trawl fisheries of Qatar and is marketed for low value. The species is sold in fish markets in the Western Atlantic and is a highly rated bait for sailfish (Smith-Vaniz, 2002). It is targeted of Grenada for medium-scale commercial fisheries (Baldeo, 2011). It is a minor commercial species off Cuba, Jamaica, and in the U.S. Virgin Islands. Global aggregate catch data for $\mathrm{S}$. crumenophthalmus between 1950 - 2011 shows an increasing trend.

Pampus argenteus (Temminck and Schlegel, 1843) is a species of butterfish that lives in coastal waters off the Middle East, South Asia, and Southeast Asia. The species now also occurs in the Mediterranean, having colonized it as part of Lessepsian migration through the Suez Canal. Fish of this family are characterized by their flat bodies, forked tail fins, and long pectoral fins (Rodríguez and Suárez, 2001). This species can found in benthopelagic; oceanodromous and marine with depth range $5-110 \mathrm{~m}$. This fish is prized in the Indo-AsiaPacific region for its taste. It's flesh is soft and buttery when cooked. This species also used as fisheries, highly commercial, price category high, reliable price based on ex-vessel price for this species (Froese and Pauly, 2019).

Stolephorus sp. is a species that including cartilaginous or bony (hard boned). This species is pelagic with inhabits coastal and estuary waters, but some species can live in low salinity of $10-15 \%$. Stolephorus sp. live in groups, often migrating, and distribution area that is affected by seasonal changes in certain areas. Seasonal pattern of Stolephorus sp. occurs periodically every year. This species has a wide distribution area in the Pacific Ocean and even reaches Tahiti and Madagascar. Distribution Stolephorus sp. covers almost all regions of Indonesia. Stolephorus sp. is an important economic commodity. This fish is utilized as a food source with a variety of processed and preserved foods from Stolephorus sp. (Luasunaung, 2011).

Auxis rochei (Risso, 1810) is the smallest among all tuna species in the world. Fish of the genus Auxis, are epi/meso-pelagic, having a worldwide distribution in tropical and subtropical waters with a seasonal coastal distribution in temperate and tropical areas. This species is cosmopolitan in warm waters and is present in the Atlantic, Indian, and Pacific oceans, including the Mediterranean Sea. This is a pelagic, oceanodromous species that forms schools. It is an off-shore predator feeding on whatever abundant resource is available with a preference for planktonic crustaceans, small cephalopods, and fish larvae (Mostarda et al., 2007). This species is fished throughout its range, with high regional importance in some areas. A. rochei has become a major species in the fishery and is exploited on a commercial scale throughout the year. The average annual catch $(2006-2010)$ is estimated at 3,131 t contributing $1.7 \%$ to the total tuna landings (Jasmine et al., 2013).

\section{Fish Distribution}

Fishermen in Baron Beach have their own methods of selling catches fish. According the results of interviews and observation, researcher found after fisherman getting off form the boat, many people were waiting to buy catches fish. After that the fish will be distribute in fish auction place (TPI) which has become a market place for fisherman to sell their catch.

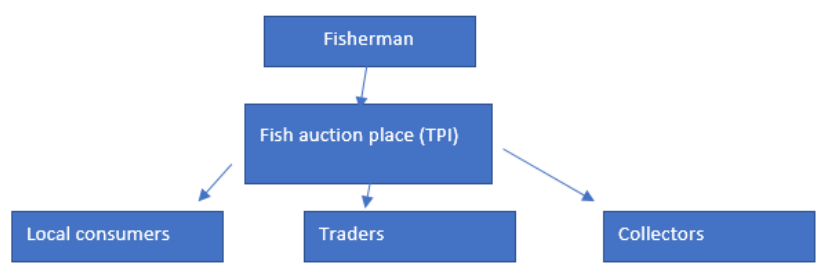

Figure 1. Scheme of Fish Distribution.

The Distribution of Fish in Baron Beach has several stages of process.Based on the researcher mapping result, there are 3 fish distribution patterns on the Baron Beach;

1. Fish sales are conducted by fishermen at the fish auction place. Consumers who come from the local area will buy directly from fisherman.Usually the price sale is cheaper because the consumers already have relation to fisherman. Consumer also often buy fish only for personal consumption.

2. Fish sales to local Baron Coast sellers, generally fish caught by fishermen are bought by local trader to be processed into seafood. After that local baron sellers will sell the food during the holidays, the sellers are usually woman or the wife of baron beach fisherman. The Price of the fish after being processed could be increase twice, especially when holiday season.

3. The Fish sales directly to wholesalers or traders, In this case fishes are bought by fish broker in the large amount to be distributed in various places or district.

\section{Social Welfare in Baron Beach}

Basically the abundance of fish has an impact on the welfare of fishermen, buyers and traders. Especially in this seasonal differences some species of fish increasing significantly. Moreover, tourist on the baron beach is also increasing quite a lot, the impact of the community during the transition of season include; 
a. Economy

Seasonal transition has a positive impact on the amount of fishermen's catch. On October until November every boat could take fish up to $1500 \mathrm{~kg}$ or 1.5 quintal once at sea. Some type of fish such as Euthynnus affinis, Elagatis bipinnulata, Katsuwonus pelamis, Scomberomorus sp. and Selar crumenophthalmus become abundant. When the fish is sold directly by fishermen the price is around 10,000 rupiahs until 50,000 rupiah depends on the type of fish. After the fish is bought by local seller and being processed became seafood, the price could increase twice per $\mathrm{kg}$.

b. Social

The change of seasons also has positive impact on the social aspect. In this season fisherman have more opportunity sail to the sea. Certainly those require help by many people to lift the ship to the sea, fisherman that do not sailing help another fisherman by pulling the ship to the sea or land. The value of gotong royong (mutual cooperation) slowly increase along with many ships that sailing to the sea.

c. Culture

During the abundant fish season, people held special traditional event which is called as sedekah laut (alms sea). It is volunteering activity by community as a form of gratitude to the creator. Sedekah laut or familiarly known as Labuan is an anchored activity (melarung) some variety traditional dish like Gunungan Tumpeng (cone-shaped rice), Ingkung (grilled chicken), Jajan Pasar (traditional snakcs), and Sesajen (offerings) which symbolize as life.

\section{CONCLUSION}

Conclusion from this study is the diversity of fish species at most in harvest season are Euthynnus affinis, Elagatis bipinnulata, Katsuwonus pelamis, Scomberomorus sp. and Selar crumenophthalmus. Diversity at most on the rainy season is Pampus argenteus, while in the dry season are Stolephorus sp., Elagatis bipinnulata, and Auxis rochei. The method of selling fish was done through fishermen, brought to the fish auction to bought by collectors, traders, and consumers. The selling price of fish on traders and collectors has doubled from the fishermen. The abundance of crops has an impact on welfare of fishermen, consumers and traders. The harvest season also has positive impact on social, tourism and culture. The conclusion from this study is the seasonality affects to diversity of fish species, selling price is relatively stable, and has positive impact on society in terms of economic, social, cultural and tourism.

\section{ACKNOWLEDGEMENTS}

Thank you to the Department of Research and Development, Tourism Ambassador of Gunungkidul for providing the opportunity to realize a research work program for the first time. Hopefully the work of this department can contribute significantly to development in Gunungkidul.

\section{REFERENCES}

Arai T, Kotake A, Kayama S, Ogura M and Watanabe Y. 2005. Movements and life history patterns of the skipjack tuna Katsuwonus pelamis in the western Pacific, as revealed by otolith Sr: Ca ratios. J. Mar. Biol. Assoc. UK 85: 1211 - 1216.

Badan Pusat Statistik (BPS). 2016. DIY Dalam Angka Tahun 2016. BPS, Yogyakarta.

Baldeo R. 2011. Coastal Fisheries of Grenada. In: S. Salas, R. Chuenpagdee, A. Charles and J.C. Seijo (eds), Coastal fisheries of Latin America and the Caribbean FAO, Rome.

Collette BB. 2001. Scombridae. In: K.E. Carpenter and V. Niem (eds), The Living Marine Resources of the Western Central Pacific. FAO, Rome.

Collette BB and Nauen CE. 2019. FAO Species Catalogue. Scombrids of the world. An annotated and illustrated catalogue of Tunas, Mackerels, Bonitos and related species known to date. FAO Fish. Synop 125(2): 137.

Cresswell JW. 2014. Research Design Qualitative, Quantitative and Mixed Method Approach's. Sage Publication, London.

Environment Agency. 2013. Annual Fisheries Statistics Report for Abu Dhabi Emirate 2012. Biodiversity Management Sector, Abu Dhabi.

FAO.2014.

http://www.fao.org/fishery/statistics/software/fishstat/en. Retrieved November 25, 2019, from http://www.fao.org.

Froese R and Pauly D. Pampus argenteus (Euphrasen, 1788). [online] India Biodiversity Portal. Available at: https://indiabiodiversity.org/biodiv/species/show/233008 (Accessed on 25 November 2019).

Gonzalez EC and Olarte YG. 2004. Structure of Pelagic Smallscale Fishery in San Andres Island, Occidental Caribbean. 55: 1018.

Hanafi T. 2019. Economic Empowerment of Mina Samodra Fisherman Community in Baron Beach, Desa Kemadang, Kecamatan Tanjungsari, Gunungkidul Regency. [Thesis]. Sunan Kalijaga State Islamic University, Yogyakarta.

Harijiyanti FR. 2001. Community participation in the preservation of coral reef at the coastal area of Gunungkidul Regency. Jurnal Manusia dan Lingkungan 8: 49-60.

Herlina E. 2017. Diversity of Fish Consumption Results of Service Catches at TPI Gunungkidul Beach, Yogyakarta. [Thesis]. Islamic Sunan Kalijaga State Islamic University, Yogyakarta.

IOTC. 2008. Report of the Tenth Session of the IOTC Working Party on Tropical Tunas. IOTC, Bangkok.

Jasmine S, Rohit P, Abdussamad EM, Koya KPS, Joshi KK, Kemparaju S, Prakasan D, Elayathu MNK and Sebastine M. 2013. Biology and fishery of the bullet tuna, Auxis rochei (Risso, 1810) in Indian waters. Indian J. Fish. 60(2): 13 - 20. 
Kasim K and Triharyuni S. 2014. Status pemanfaatan dan musim penangkapan ikan tenggiri (Scomberomorus spp.) di Laut Jawa. J. Lit. Perikan. Ind. 20(4): 235 - 242.

Kusumastuti AH and Pamungkas A. 2018. Identifikasi potensi dan permasalahan daya dukung lingkungan berdasarkan aspek daya dukung fisik, daya dukung ekologis, dan daya dukung sosial pada Pantai Baron, kabupaten Gunungkidul, Yogyakarta. Jurnal Teknik ITS 7(1): 2337 - 3520.

Laevastu T and Hayes LM. 1981. Fisheries Oceanography and Ecology. Fishering News Book Ltd, New York.

Laevastu T and Hela I. 1970. Fisheries Oceanography. Fishering News Book Ltd., London.

Luasunaung A. 2011. Analisis musim penangkapan ikan teri (Stolephorus sp.) di Teluk Dodinga, Kabupaten Halmahera Barat. Jurnal Perikanan dan Kelautan Tropis 7(1): 6 - 11 .

Mann KH and Lazier JRN. 1996. Dynamic of Marine Ecosystem, Biological-Physical Interaction in The Oceans, Second edition. Blackwell Science, USA.

Maunder MN. 2010. Updated Indicators of the Stock Status for Skipjack Tuna in the Eastern Pacific Ocean. In: IATTC (ed.), Scientific Advisory Committee 1st Meeting 31 August-3 September 2010. IATTC, La Jolla.

Maypa AP, Russ GR, Alcala AC and Calumpong HP. 2002. Longterm trends in yield and catch rates of the coral reef fishery at Apo Island, central Philippines. Marine and Freshwater Research 53: 207 - 213.

Noegroho T and Umi C. 2015. Parameters and recruitment pattern of Bullet Tuna (Auxis rochei Risso, 1810) In West Coast Sumatera. Jurnal Bawal 7: 129-136.

Mostarda E, Campo D, Castriota L, Esposito V, Scarabello MP and Andaloro F. 2007. Feeding habits of the Bullet Tuna Auxis rochei in the southern Tyrrhenian Sea. Journal of the Marine Biological Association of the United Kingdom 87: 10071012.

Nurdin E., et al. 2012. Optimalisasi jumlah rumpon, unit armada dan musim penangkapan perikanan Tuna di Perairan Prigi, Jawa Timur. J. Lit. Perikanan. Ind. 18: 53 - 60.

Pinheiro PB, Hazin FHV, Travassos P, Oliveira PGV, Carvalho F and Rego MG. 2011. The reproductive biology of the rainbow runner, Elagatis bipinnulata (Quoy \& Gaimard, 1825) caught in the Sao Pedro and Sao Paulo Archipelago. Brazil Journal of Biology 71(1): 99 - 106.

Qu T, Du Y, Strachan J, Myers G and Slingo J. Sea Surface Temperature and Its Variability in Indonesian Region. Journal Oceanography 18(4): $50-61$.

Rodríguez G and Suárez H. 2001. Anthropogenic dispersal of decapod crustaceans in aquatic environments. Interciencia 26(7): $282-288$.

Roos D, Roux O and Conand F. 2007. Notes of the biology of the bigeye scad, Selar crunelophthalmus (Carangidae) around Reunion Island, southwest Indian Ocean. Scientia Marina 71(1): $137-144$

Sahubawa, Latif, Khakim N and Lasindrang M. 2015. kajian sebaran potensi ekonomi sumber daya kelautan di pantai selatan Daerah Istimewa Yogyakarta sebagai upaya percepatan investasi. Jurnal Teknosains 4(2): $101-120$.

Simon T, Macieira RM and Joyeux JC. 2013. The shore fishes of the Trindade-Martin Vaz insular complex: an update. Journal of Fish Biology 82(6): 2113 - 2127.

Smith-Vaniz WF. 2002. Carangidae (Jacks and scads - bumpers, pompanos, leatherjacks, amberjacks, pilotfishes, rudderfishes). In: K.E. Carpenter (ed.), The Living Marine Resources of the Western Central Atlantic Volume 3 Bony fishes part 2 (Opistognathidae to Molidae), sea turtles and marine mammals, pp. 1426-1468. FAO, Rome.

Smith-Vaniz WF, Williams JT, Brown J, Curtis M and Amargos FP. 2015. Selar crumenophthalmus (errata version published in 2017). The IUCN Red List of Threatened Species 2015: e.T190388A115316971. http://dx.doi.org/10.2305/IUCN.UK.2015-

4.RLTS.T190388A16510647.en. (Accessed on 24 November 2019).

Suadi. 2002. From farmers became fisher: a historical study of South Coastal Yogyakarta marine capture fishier. Jurnal Perikanan UGM 4: 05 - 12.

Sudarmin et al. 2016. Elastisitas tingkat penjualan ikan Panggandeng terhadap perubahan musim di Kelurahan Tamalera Indah Makasar. Jurnal Scientific Pinsi 2: 124 - 130. 